\title{
WHAT DRIVES ECONOMIC GROWTH IN SOME CEE COUNTRIES?
}

\author{
Mihaela Simionescu, dr. hab. \\ Institute for Economic Forecasting of the Romanian Academy \\ Centre for Migration Studies in Prague Business School \\ E-mail: mihaela_mb1@yahoo.com
}

(Received: October 2017; Accepted February 2018)

\begin{abstract}
Considering the potential factors that might generate economic growth, a target for any economy, this paper identified some determinants of economic growth in the countries from Central and Eastern Europe (CEE countries) that are member states of the European Union. The foreign direct investment was the most important determinant of economic growth in most of the countries (Bulgaria, Slovenia, Estonia, Hungary, Romania, Poland, Latvia, Lithuania) in the period 2003-2016, according to Bayesian bridge regressions. The indicators related to the level and the quality of labour resources proved to be insignificant in explaining the economic growth in these countries. Moreover, in Croatia, Estonia, Latvia, Lithuania, and Poland, the government expenditure on education had a negative effect on economic growth.

Key words: economic growth, foreign direct investment, Bayesian ridge regression, CEE countries
\end{abstract}

\section{J.E.L. CODES: C53, 047}

\section{Introduction}

Central and Eastern European countries (CEEC) were considered underdeveloped states compared to Western European countries, because of the lack of necessary resources and technological levels. Their economic growth was mostly conditioned by foreign investment. The economic development of these states was conditioned by the political changes in the objective of getting the transformation from controlled economy to a capitalist market economy.

The main aim of this paper is to identify some factors that explain the economic growth in some countries from Central and Eastern Europe that are member of the European Union (Bulgaria, Croatia, Czech Republic, Slovak Republic, Slovenia, Estonia, Hungary, Romania, Poland, Latvia, and Lithuania). Among the potential determinants of economic growth, we selected more variables related to human resources, but also to other macroeconomic indicators: employment rate, expenditure on education and research and development (R\&D) sector, labour force with secondary and tertiary education, foreign direct investment (FDI) and inflation rate. Due to small sets of data (2003-2016), a Bayesian approach is employed. The Bayesian fast ridge regression model is employed to select the best

46 DE GRUYTER OPEN
Studia Universitatis "Vasile Goldis" Arad. Economics Series Vol 28 Issue 1/2018 ISSN: 1584-2339; (online) ISSN: $2285-3065$

Web: publicatii.uvvg.ro/index.php/studiaeconomia.Pages 46 - 56 
predictor of the economic growth in each country. In most of the mentioned countries, the FDI was an engine of the economic growth. In none of the countries, the expenditure on education and R\&D and more skilled people did not bring a significant economic growth.

The novelty of this research is given by the fact that a Bayesian approach is applied to identify the determinants of economic growth even on a small set of data. The results confirmed the recent findings in literature regarding the role of FDI in achieving economic growth. Moreover, other variables regarding education and labour resources are included. Even if the theoretical approaches considered that investment in human resources can generate economic growth (Garavan et al. (2016)), our empirical findings proved that in the case of CEE countries, the quality and quantity of labour resources are not relevant in explaining the economic development.

After this introduction, some key points from literature are described. The next section is dedicated to methodological framework while the fourth part presents the empirical results. The last part concludes.

\section{Literature review}

The economic theory considers that economic growth is stimulated by factors coming from different areas: the quality and quantity of human resources that are available in a country, technological development, natural resources, capital formation and social and political factors.

The economic theory indicated a positive connection between GDP rate and employment rate. If economic growth is studies in more countries, Chubrik (2005) proposes a single regression for each state in case of high correlations between regressors. However, recent studies recommended the Panel Data Approach for explaining GDP growth rate in a sample of countries such as those from the European Union. The main advantages of panel data lie in the fact that they comprise more informative data, show more variability, display a higher number of degrees of freedom, present less colinearity between variables and estimators are more efficient. Other possibility of explaining economic growth is by using a theory of endogenous fiscal policy and growth which was used in the study of Barseghyan and Battaglini (2016). They state that the growth depends on public investment, private investment and labor supply. A fiscal policy is determined through the legislative bargaining. The relationship between economic growth and financial market development is analyzed by Borlea et al. (2016) who showed variations among regions.

In the study by Tas, Hepsen and Onder (2013), the gross domestic product in the EU countries and in several EU candidates in the period from 2002 to 2012 is

DE GRUYTER OPEN
Studia Universitatis "Vasile Goldis" Arad. Economics Series Vol 28 Issue 1/2018 ISSN: 1584-2339; (online) ISSN: $2285-3065$

Web: publicatii.uvvg.ro/index.php/studiaeconomia.Pages $46-56$ 
explained based on panel data models using as explanatory variables: General government total expenditure, general government gross debt, current account balance, inflation rate (based on average consumer prices), unemployment rate, gross national savings, general government revenue, exports of goods and services, imports of goods and services, population, total investment. The Population size positively influences economic growth, while unemployment rate and total expenditure have a negative impact on economic growth. Mielcová (2011) or Flek and Mysíková (2015) conducted research on the correlation between factors such as unemployment and economic growth in a country. Ono and Uchida (2016) have researched the effects of population aging on these policies and economic growth from a political economy perspective. They state that a very interesting factor influencing economic growth is the competition between generations regarding public education and public pensions.

Patillo et al. (2004) employed a large panel data set including 61 developing over 1969-1998 to show that the "external indebtedness" had a negative effect on the economic due to adverse effects on overall factor productivity growth and physical capital accumulation.

Furceri and Karras (2008) analyzed the effects of taxes change on the economic growth of 26 countries of OECD. They employed a panel data model over 19652007. Each increase in taxes by 1 percentage point brought a decrease in real GDP per capita by 0.5 percentage points up to 1 percentage point. The increase in the social security contributions and in the taxes on goods and services had a higher impact on real GDP per capita compared to the income tax.

A Panel Data Analysis was proposed by Hussin and Saidin (2012) for ASEAN countries to assess the effects on GDP of more variables: Foreign direct investment, Openness, and gross fixed capital formation. A fixed effects model, a pooled model and a random effects model were estimated in the period 1981-2008. All the mentioned variables were positively connected with GDP, but the Panel Data approach indicated that for all countries from ASEAN group (Thailand, Malaysia, Philippines, and Indonesia) FDI was not correlated with GDP.

Economic growth is not strictly determined by the evolution of economic indicators. There are also determinants from social and political sphere. According to Radu (2015), the economic growth in the CEE countries was also influenced by political factors like political certainty, political stability and political freedom in the period 1990-2010.

There are some studies that considered education as an important determinant of the economic growth, even in the countries from Central and Eastern Europe. For example, Cuaresma et al. (2014) employed the Bayesian model averaging to identify the determinants of the economic growth in 255 European regions in the 
period from 1995 to 2005. Catching-up regions in terms of income were identified in the new member countries of the Central and Eastern Europe. The regions around capitals grew faster because of the high-educated employees. A comparative study of Noja et al. (2014) showed that both in OECD countries and in the CEE states, the education is the most significant determinant of the economic growth. If the macroeconomic policies promote human capital development, the developing countries have more chances to accelerate economic growth.

Globalization was another significant determinants of the economic growth in CEE countries over 1990-2009. Gurgul and Lach (2014) identified some dimensions of globalization that had a strong impact on the CEE countries economic growth in the mentioned period: economic globalization (less import barriers, international trade development, more foreign investment, tax policy development), social sphere of globalization (television, internet, newspapers), and information flow. On the other hand, political globalization did not significantly stimulate economic growth in these countries. Moreover, Capello and Perucca (2015) showed that globalization had a positive influence on EU integration and stimulated the economic performance of CEE countries. The same authors showed in a study from 2016 that industrial restructuring played a significant in the CEE regions' economic growth. Capello and Perucca (2016) showed that the zones that reconverted the productive specialization to higher value functions and new sector succeeded in achieving the highest economic growth. For Romania, the relation between economic growth and globalization was studied by Neagu and Dima (2017) who showed a strong connection between the GDP per capita rate and index of globalization in the period 1990-2013.

Supińska (2013) employed a spatial approach to identify the determinants of economic growth in the regions belonging to 10 CEE countries in the period from 1999 to 2008. The author estimated spatial error and spatial lagged models to show that economic growth was determined by the level of human capital, changes in the human capital and the regions' location.

\section{Methodology}

The classical regression models could offer misleading results using empirical data, the cause being related to the violation of the method assumptions. Therefore, the regression model should present all possible data patterns. This disadvantage is solved by the Bayesian nonparametric approach that builds flexible models as an infinite mixture of regression models using the fewest assumptions on data.

The ridge regression linear model proposes estimates via shrinkage and the prediction error and the mean squared error are, in most cases, improved. 
Given a specific data series, $D_{n}=(X, y)$ with $X=\left(x_{i p}\right)_{n x p}$ and $y=\left(y_{1}, \ldots, y_{n}\right)^{T}$ and a conjugate normal-inverse gamma prior density to $\left(\beta, \sigma^{2}\right)$, O'Hagan and Forster (2004) showed that:

$$
\begin{gathered}
f\left(y \mid X, \beta, \sigma^{2}\right)=n_{n}\left(y \mid X \beta, \sigma^{2} I_{n}\right)=\prod_{i=1}^{n} n\left(y \mid x_{i}^{T} \beta, \sigma^{2}\right) \\
\pi\left(\beta, \sigma^{2}\right)=n_{p}\left(\beta \mid m, \sigma^{2} V\right) i g\left(\sigma^{2} \mid a, b\right)=n i g\left(\beta, \sigma^{2} \mid m, V, a, b\right)
\end{gathered}
$$

$n_{n}(. \mid \mu, \Sigma)$ - probability density function (pdf) of the $\mathrm{n}$-variate normal distribution $n\left(. \mid \mu, \sigma^{2}\right)$ - probability density function (pdf) of the uni-variate normal distribution $\operatorname{ig}(. \mid a, b)-$ probability density function (pdf) of the inverse gamma distribution (a represents the shape and $\mathrm{b}$ the rate, $1 / \mathrm{b}$ - scale)

nig $\left(\beta, \sigma^{2} \mid m, V, a, b\right)$ - probability density function (pdf) of the NIG distribution (product of 2 pdf functions corresponding to the inverse-gamma and multivariate normal, according to Lindley and Smith, 1972 )

If joint prior distribution of $\left(\beta, \sigma^{2}\right)$ follows a NIG distribution, in the marginal approach, $\beta$ follows a Student prior distribution of mean $\mathrm{m}$ and covariance matrix $V 1(\beta)=\frac{b}{a-1} V$ and 2 a degrees of freedom. $\sigma^{2}$ follows an inverse-gamma prior distribution of mean $\frac{b}{a-1}$ and variance $\frac{b^{2}}{(a-1)^{2}(a-2)}$.

Karabatsos (2014) explained that the ridge regression model (RR model) represents a Bayesian linear regression model of normal prior distribution $n_{p}\left(\beta \mid 0, \sigma^{2} \lambda^{-1} I_{p}\right)$ for $\beta$, conditionally on $\sigma^{2}$. If $\left(\beta, \sigma^{2}\right)$ follows a prior normal inverse-gamma distribution $\operatorname{nig}\left(\beta, \sigma^{2} \mid 0, \lambda^{-1} I_{p}, a, b\right)$, the inferential procedures for Bayesian normal linear regression model are employed to a ridge regression.

The singular value decomposition (svd) for design matrix $\mathrm{X}$ is $X=U D W^{T}$. Here, $\mathrm{U}$ and $\mathrm{W}$ are orthogonal matrices of $\mathrm{n} \times \mathrm{q}$, respectively $\mathrm{p} \times \mathrm{q}$, where $\mathrm{q}=\min (\mathrm{n}, \mathrm{p})$ and $\mathrm{Z}=\mathrm{UD}=\mathrm{XW}$.

$D=\operatorname{diag}\left(d_{1}, \ldots, d_{q}\right)$ is a diagonal matrix of singular values $d_{1}>d_{2}>\cdots>d_{q}>$ 0

$\left(d_{1}^{2}, \ldots, d_{q}^{2}\right)$ gives at most the first $\mathrm{q}$ eigenvalues (q different from $0, q \leq$ $p)\left(d_{1}^{2}, \ldots, d_{q}^{2}\right)^{T}$ of $X^{T} X$ and gives the diagonal values of $Z^{T} Z$.

The $\mathrm{q}$ principal components of $\mathrm{X}$ are presented in the columns of $\mathrm{XW}$. The column-wise sum of squares over the rows represents the eigenvalues $\left(d_{1}^{2}, \ldots, d_{q}^{2}\right)$. Considering orthogonalized data $(\mathrm{Z}, \mathrm{y})$, the multivariate normal likelihood density for canonical normal linear model is:

$$
n_{n}\left(y \mid X W \alpha=Z \alpha=X \beta, \sigma^{2} I_{n}\right)
$$

The OLS estimate for parameters of canonical regression is: 


$$
\hat{\alpha}=\operatorname{diag}\left(d_{1}^{2}, \ldots, d_{q}^{2}\right)^{-1} Z^{T} y
$$

The OLS estimate corresponding to slope is:

$$
\hat{\beta}=W \hat{\alpha}
$$

The conditional prior distribution for $\beta=W \alpha$, when $\sigma^{2}$ is known, follows a multivariate normal pdf that is the prior distribution (pdf) for generalized ridge regression:

$$
\pi\left(\beta \mid \sigma^{2}\right)=n\left(\beta \mid 0, \sigma^{2} W V_{\lambda}^{(\alpha)} W^{T}\right)
$$

A particular case for the generalized ridge regression is represented by the ordinary ridge regression (RR). It is based on the assumption that $\lambda=\lambda_{1}=\lambda_{2}=\cdots=\lambda_{q}$. In this case, we have:

$$
\begin{aligned}
& \pi\left(\beta \mid \sigma^{2}\right)=n\left(\beta \mid 0, \sigma^{2} \lambda^{-1} I_{p}\right) \\
& \pi\left(\alpha \mid \sigma^{2}\right)=n\left(\alpha \mid 0, \sigma^{2} \lambda^{-1} I_{p}\right)
\end{aligned}
$$

The ridge regression allows for a rapid OLS estimation of the coefficients, even if the number of covariates $(p)$ is very large and the number of covariates is higher than the number of observations. The case based on a large number of parameters is specific to Bayesian nonparametric models. The models specification with many parameters is realized for getting robust and flexible statistical inference. Griffin and Brown (2013) explained that Bayesian ridge regression uses simple prior structure and has a good predictive performance in many cases.

For a flexible linear model where $\mathrm{p}$ increases with $\mathrm{n}$, the mean function is represented as:

$$
E(Y \mid x)=X^{T} \beta=\sum_{k=1}^{L} \beta_{k} x_{k}+\sum_{i=1}^{n} \beta_{i} B_{i}(x)
$$

$B_{i}(x)$ - multivariate spline

$\sum_{i=1}^{n} \beta_{i} B_{i}(x)$ consists in a linear combination of basis functions that includes the departures of linearity of the regression function

According to Polson and Scott (2012), Levy processes might describe the high dimensional shrinkage linear regression models.

In this empirical application, estimations will be provided and we will determine the posterior probability that the standardized coefficient is within 1 standard deviation of 0 (PP1SD). If the value of PP1SD is less than 0.5 , then the exogenous variable is considered a significant predictor in the ridge regression.

\section{Determinants of economic growth in some CEE countries}

The data series used in this empirical analysis refer to the following variables: real GDP growth (\%), employment rate (\%), inflation rate (\%) based on harmonized price index, provided by Eurostat and FDI inflows as \% of GDP, government 
expenditure on education as \% of GDP, expenditure on research and development (\% of GDP), labour force with secondary and tertiary education (\% of total) provided by World Bank database. The data are provided for the period 2003-2016 for the following CEE countries: Bulgaria, Croatia, Czech Republic, Estonia, Hungary, Latvia, Lithuania, Poland, Slovakia, Romania and Slovenia. The data for real GDP rate in 2016 are provisional and they are subject to revisions.

We applied the Bayesian Ridge Regression to identify the best predictors in explaining the economic growth for each country. This approach is suitable, because we have a small set of available data for each country (2003-2016).

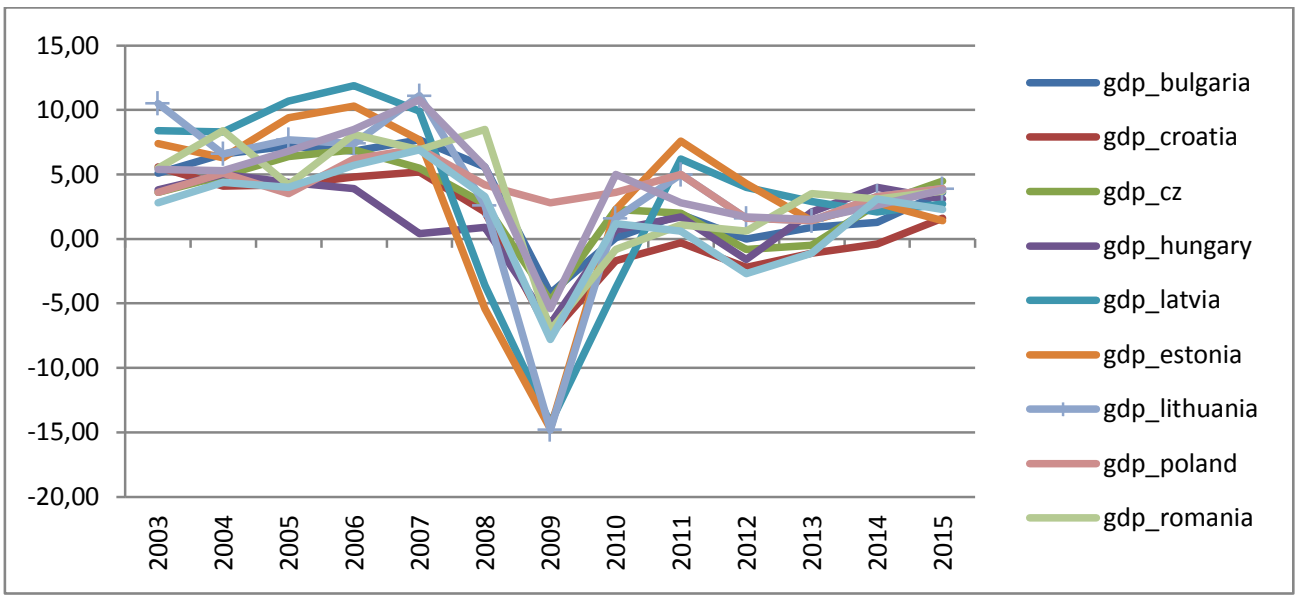

Figure 1 The real GDP rate evolution in some CEE countries (2003-2015) Source: author's graph

As we can observe from Figure 1, in the period 2008-2010, in the context of recent economic crisis, GDP rates dramatically decreased, arriving in most cases to negative values. Poland was the only country that did not have any negative value during this period.

In the case of Bulgaria, the determinants of economic growth in the period 20032016 were: employment rate, inflation rate, labour force with secondary education and FDI inflows. Contrary to expectations, employment rate had a negative effect on economic growth. Higher the employment rate was, lower the economic growth was. The negative relationship between economic growth and employment, contrary to economic theory, might be explained by the fact that in times of economic crisis the companies adapted by reducing the number of hours of working. The inflation rate had a positive impact on economic growth. Even if the 
prices were less stable, the real GDP continued to increase. The increase in the weight of labour force with secondary education generated less economic growth. Less educated people have lower salaries than higher educated ones which might explain the less economic growth. The most significant impact on economic growth belonged to FDI inflows that were a source of economic growth for Bulgaria in the period 2003-2016. An increase in FDI inflows as \% of GDP by one percent generated an increase in the economic growth by 1.819 percentage points. In the case of Croatia, Slovak Republic and Czech Republic, none of the mentioned determinants was relevant in explaining the economic growth.

Table 1. Slope estimates for Bayesian bridge regression models

\begin{tabular}{|l|l|l|l|l|l|l|l|}
\hline Country & $\begin{array}{l}\text { Employment } \\
\text { rate }\end{array}$ & $\begin{array}{l}\text { Inflation } \\
\text { rate }\end{array}$ & $\begin{array}{l}\text { Government } \\
\text { expenditure } \\
\text { on } \\
\text { education as } \\
\text { \% of GDP }\end{array}$ & $\begin{array}{l}\text { Labour } \\
\text { force with } \\
\text { secondary } \\
\text { education } \\
(\% \text { of total) }\end{array}$ & $\begin{array}{l}\text { Labour } \\
\text { force with } \\
\text { tertiary } \\
\text { education } \\
(\% \text { of } \\
\text { total) }\end{array}$ & $\begin{array}{l}\text { Expenditure } \\
\text { on research } \\
\text { and } \\
\text { development } \\
\text { (\% of GDP) }\end{array}$ & $\begin{array}{l}\text { FDI } \\
\text { inflows } \\
\text { as } \% \text { of } \\
\text { GDP }\end{array}$ \\
\hline Bulgaria & -0.907 & 1.235 & -0.291 & -0.957 & 0.737 & $0.137(0.66)$ & 1.819 \\
& $(0.415)$ & $(0.345)$ & $(0.61)$ & $(0.304)$ & $(0.542)$ & & $(0.092)$ \\
\hline Croatia & $0.269(0.639)$ & 0.176 & -1.883 & -0.336 & -0.510 & 0.268 & 0.476 \\
& & $(0.652)$ & $(0.069)$ & $(0.620)$ & $(0.582)$ & $(0.631)$ & $(0.563)$ \\
\hline Czech & -0.006 & 0.009 & -0.066 & 0.072 & -0.073 & -0.049 & 0.064 \\
Republic & $(0.664)$ & $(0.664)$ & $(0.647)$ & $(0.644)$ & $(0.643)$ & $(0.655)$ & $(0.648)$ \\
\hline Estonia & -0.831 & -0.140 & -5.353 & 2.044 & -1.047 & 0.948 & 0.702 \\
& $(0.602)$ & $(0.662)$ & $(0.001)$ & $(0.484)$ & $(0.614)$ & $(0.575)$ & $(0.602)$ \\
\hline Hungary & $0(0.664)$ & $0(0.664)$ & $0(0.664)$ & $0(0.664)$ & $0(0.664)$ & $0(0.664)$ & $0(0.664)$ \\
\hline Latvia & -0.550 & -1.205 & -3.059 & 0.131 & -0.457 & -0.233 & 1.604 \\
& $(0.606)$ & $(0.449)$ & $(0.066)$ & $(0.663)$ & $(0.649)$ & $(0.656)$ & $(0.423)$ \\
\hline Lithuania & -0.046 & -2.082 & -3.137 & 0.311 & -1.274 & -0.506 & 1.952 \\
& $(0.664)$ & $(0.192)$ & $(0.101)$ & $(0.658)$ & $(0.561)$ & $(0.643)$ & $(0.281)$ \\
\hline Poland & -0.024 & -0.019 & $-0.8(0.093)$ & $0.466(0.52)$ & -0.314 & $-0.3(0.295)$ & 1.168 \\
& $(0.602)$ & $(0.665)$ & & $(0.602)$ & & $(0.000)$ \\
\hline Romania & $0.019(0.664)$ & 0.207 & -0.180 & 0.204 & -0.342 & -0.135 & 0.94 \\
& & $(0.647)$ & $(0.65)$ & $(0.648)$ & $(0.621)$ & $(0.656)$ & $(0.375)$ \\
\hline Slovak & -0.039 & 0.154 & -0.375 & $0.077(0.66)$ & -0.254 & -0.218 & 0.480 \\
Republic & $(0.663)$ & $(0.647)$ & $(0.565)$ & & $(0.62)$ & $(0.628)$ & $(0.514)$ \\
\hline Slovenia & -0.296 & 0.638 & -0.230 & -0.281 & -0.323 & -0.51 & 2.251 \\
& $(0.638)$ & $(0.557)$ & $(0.65)$ & $(0.65)$ & $(0.647)$ & $(0.616)$ & $(0.018)$ \\
\hline Source: & & & & & & \\
\hline
\end{tabular}

Source: author's calculations

Note: PP1SD in brackets

For Estonia, Lithuania and Latvia, there was a negative correlation between economic growth and government expenditure on education. Even if the expenditure on education grew, the GDP decreased. For Latvia, FDI inflows had a positive impact on economic growth. An increase in FDI inflows as \% of GDP by one percent in Latvia generated an increase in the economic growth by 1.604 percentage points. An increase in FDI inflows as \% of GDP by one percent in

DE GRUYTER OPEN
Studia Universitatis "Vasile Goldis" Arad. Economics Series Vol 28 Issue 1/2018 ISSN: 1584-2339; (online) ISSN: 2285 - 3065 
Lithuania generated an increase in the economic growth by 1.952 percentage points. On the other hand, the decrease in inflation rate in Latvia and Lithuania (more stable prices) generated economic growth in these countries.

In the case of Poland, the increase of government expenditure on education did not generate economic growth (at each increase in expenditure on education by 1 percentage point, the GDP decreased by 0.8 percentage points). The increase in the expenditure for research and development did not bring economic growth (at each increase in expenditure on R\&D by 1 percentage point, the GDP decreased by 0.3 percentage points).

In the case of Romania and Slovenia, only FDI inflows generated economic growth. An increase in FDI inflows as \% of GDP by one percent in Romania generated an increase in the economic growth by 0.94 percentage points. Each increase in FDI inflows as \% of GDP by one percent in Slovenia generated an increase in the economic growth by 2.251 percentage points.

All in all, excepting Croatia, Slovak Republic and Czech Republic, all the other countries registered economic growth in the period 2003-2016 due to FDI inflows. The expenditure on education or R\&D did not bring the expected growth in GDP. The results are consistent with the empirical findings of Hlavacek and BalDomanska (2016). However, in the near future, the foreign investors will place their investment in other European states that are more cost-effective Tun, AzmanSaini and Law, 2012).

\section{Conclusions}

In this paper, various types of determinants of the economic growth were considered starting from the theoretical references from literature and from the empirical findings in literature. Many studies considered that the human resources play an essential role in achieving economic growth (Hughes and Weisbrod, 2016; Murphy and Topel, 2016; Ranis et al., 2000; Mankiw et al., 1990). Our findings based on empirical data showed that aspects regarding labour force like employment, expenditure on education and $\mathrm{R} \& \mathrm{D}$, labour force with secondary and tertiary education did not generate economic growth in the CEE countries in the period 2003-2016. A possible cause for this result is related to the fact that human resources were not the subject of significant investment in order to achieve a better economic growth.

On the other hand, in most of the countries (Bulgaria, Romania, Slovenia, Poland, Lithuania, Latvia, Estonia, Hungary), the FDI provide to be an important determinant of economic growth, being in line with the findings of Neuhaus (2006) and Hlavacek and Bal-Domanska (2016). 
However, our study has a limitation given by the consideration of a few number of possible determinants. The set of predictors should be extended with variables regarding political issues, if we take into account that these CEE countries are subject to many political changes that affect the economic development. In a future study, more economic and political indicators will be considered among the explanatory variables.

\section{References}

1. Barseghyan, L., \& Battaglini, M. (2016). Political economy of debt and growth. Journal of Monetary Economics, 82, 36-51.

2. Borlea, S. N., Mare, C., Achim, M. V., \& Puscas, A. (2016). Direction of causality between financial development and economic growth. Evidence for developing countries. Studia Universitatis ,,Vasile Goldis” Arad-Economics Series, 26(2), 1-22.

3. Capello, R., \& Perucca, G. (2015). Openness to globalization and regional growth patterns in CEE countries: from the EU accession to the economic crisis. JCMS: Journal of Common Market Studies, 53(2), 218-236.

4. Capello, R., \& Perucca, G. (2016). Industrial restructuring in CEE regions: determinants of regional growth in the accession and in the crisis period. Journal of Baltic Studies, 1-21.

5. Chubrik, A., 2005. Market Reforms and Economic Growth in Post-Communist Economies: A Panel Data Approach. Policy Document Center, 1(2), 1-6.

6. Cuaresma, J. C., Doppelhofer, G., \& Feldkircher, M. (2014). The determinants of economic growth in European regions. Regional Studies, 48(1), 44-67.

7. Flek, V. and Myslíková, M., 2015. Uneployment Dynamics in Central Europe: A Labour Flow Approach. Prague Economic Papers, 24(1), 73-87.

8. Furceri, D. and Karras, G., 2008. Tax Changes and Economic Growth: Empirical evidence for a panel of OECD countries. Manuscript, University of Illinois, 1, 1-29.

9. Garavan, T. N., McCarthy, A. M., \& Morley, M. J. (Eds.). (2016). Global Human Resource Development: Regional and Country Perspectives. Routledge.

10. Gurgul, H., \& Lach, Ł. (2014). Globalization and economic growth: Evidence from two decades of transition in CEE. Economic Modelling, 36, 99-107.

11. Hlavacek, P., \& Bal-Domanska, B. (2016). Impact of Foreign Direct Investment on Economic Growth in Central and Eastern European Countries. Engineering Economics, 27(3), 294-303.

12. Hughes, H., \& Weisbrod, B. (Eds.). (2016). Human Resources, Employment and Development. New York: Springer.

13. Hussin, F. and Saidin, N., 2012. Economic Growth in ASEAN-4 Countries: A Panel Data Analysis. International Journal of Economics and Finance, 49(1), 119-127.

14. Mankiw, N. G., Romer, D., \& Weil, D. N. (1990). A contribution to the empirics of economic growth (No. w3541). National Bureau of Economic Research.

Studia Universitatis "Vasile Goldis" Arad. Economics Series Vol 28 Issue 1/2018 ISSN: 1584-2339; (online) ISSN: $2285-3065$

Web: publicatii.uvvg.ro/index.php/studiaeconomia.Pages $46-56$ 
15. Mielcová, E., 2011. Economic Growth and Unemployment Rate of the Transition Country - the Case of the Czech Republic 1996-2009. E \& M: Ekonomie a Management, 1/2011, 29-37.

16. Murphy, K. M., \& Topel, R. H. (2016). Human capital investment, inequality and economic growth (No. w21841). National Bureau of Economic Research.

17. Neagu, O., \& Dima, S. (2017). Impact of Globalisation on Economic Growth in Romania: An Empirical Analysis of Its Economic, Social and Political Dimensions. Studia Universitatis ,, Vasile Goldis” Arad-Economics Series, 27(1), 29-40.

18. Neuhaus, M. (2006). The impact of FDI on economic growth: an analysis for the transition countries of Central and Eastern Europe. Springer Science \& Business Media.

19. Noja, G., Son, L., \& Erdei, R. (2014). Comparison study on determinants of economic growth. Anale. Seria Ştiinţe Economice. Timişoara, (XX), 129-136.

20. Ono, T., \& Uchida, Y. (2016). Pensions, education, and growth: A positive analysis. Journal of Macroeconomics, 48, 127-143.

21. Patillo, C., Poirson, H. and Ricci, L., 2004. What are the Channels Through Which External Debt Affects Growth?. IMF Working Paper, 0415(1), 1-20.

22. Radu, M. (2015). The impact of political determinants on economic growth in CEE countries. Procedia-Social and Behavioral Sciences, 197, 1990-1996.

23. Ranis, G., Stewart, F., \& Ramirez, A. (2000). Economic growth and human development. World development, 28(2), 197-219.

24. Supińska, J. (2013). Does human factor matter for economic growth? Determinants of economic growth process in CEE countries in light of spatial theory. Bank $i$ Kredyt, 44(5), 505-532.

25. Tas, N., Hepsen, A. and Onder, E., 2013. Analyzing Macroeconomic Indicators of Economic Growth Using Panel Data. Proceedings of International Conference on Economic and Social Studies 1(1), 20-51.

26. Tun,Y., Azman-Saini, W. N. W., \& Law, S. (2012). International Evidence on the link between Foreign Direct Investment and Institutional Quality. Inzinerine EkonomikaEngineering Economics, 23(4), 379-386. 